\title{
Evaluation of Farmer's Perception on Deforestation and Its Impact on Agricultural Production, Gaya Local Government Area, Kano State, Nigeria
}

\author{
Dantani $\mathrm{A}^{1^{*}}$, Mukhtar RB ${ }^{1}$, Sani, MA ${ }^{2}$, Gupa MA ${ }^{3}$, Abubakar B ${ }^{4}$ \\ ${ }^{\mathrm{T}}$ Department of Forestry and Wildlife Management, Bayero University, P.M.B. 3011, Kano, Nigeria \\ ${ }^{2}$ Department of Agronomy, Bayero University, P.M.B. 3011, Kano, Nigeria \\ ${ }^{3}$ Department of Forestry and Wildlife, University of Maiduguri, P.M.B. 1069, Borno State, \\ Nigeria \\ ${ }^{4}$ Department of Forestry and Environment, Usmanu Danfodiyo University, P.M.B. 2346, Sokoto, Nigeria \\ *Corresponding Author \\ Mr. Abdulmalik Dantani
}

\section{Article History}

Received: 01.03.2020

Accepted: 09.03.2020

Published: 07.04.2020

\begin{abstract}
This study was conducted in order to assess the perception of Farmers on Deforestation and its impact on agricultural production in Gaya Local Government Area of Kano State. Stratified random sampling was adopted for this study where the study area was partitioned in to 11 wards, three districts were selected at random through balloting, and proportional sampling was used in selecting villages from the selected wards. One hundred and twenty (120) questionnaires were administered to farmers. Data collection was through interview with the farmers. Descriptive and inferential statistics were used in analyzing the data. Charts, frequency distribution and percentages were used in presenting demographic information while chi-square test of association was used to test the association between socioeconomic characteristics with ideas and causes of deforestation. The result of demography showed that, majority of the respondents fall between 48-58 years, about $91 \%$ are male and 9\% are female, $94 \%$ are farmers and $92 \%$ are married. Chi-square result revealed that there was no $(\mathrm{P}>0.05)$ significant association between socio-economic characteristics and the ideas on deforestation, on the other hand the test revealed $(\mathrm{P}<0.05)$ significant relationship between socioeconomic characteristics and the causes of deforestation with the exception of sex.
\end{abstract}

Keywords: Perception, Deforestation, Farmers, Sampling and Chi-square.

\section{INRODUCTION}

Forest area on the entire planet covers approximately 4 billion hectares. Within this, five countries (Russia, Brazil, Canada, the USA and China) have the largest area accounting for more than $50 \%$ of the entire world forest ecosystem. Forests ecosystem and woodlands covers about 675 million ha, that is $23 \%$ of Africa's land area and this constitute about $17 \%$ of global forest area [1]. The five countries with the largest forest area in Africa include Democratic Republic of Congo, Sudan, Angola, Zambia and Mozambique; together they have 55\% of the forest area on the continent [2]. Total 'planted forests in the entire world reported to be about 264 million ha. According to [2], the area of 'planted forest' in the global South increased more than 50\% between 1990 and 2010, from 95 million to 153 million ha [3]. Reported that, the total plantation area in Africa in the year 2010 was 8036000 ha comprising 3392000 ha industrial plantations, 3273000 ha non-industrial plantations and 1371000 ha unspecified plantations, which was around $4.3 \%$ of the global plantation area.

Nigeria as a country is endowed with large expanse of forested land; these include the swamp forests in the extreme Southern part of the country, the tropical rainforest in the South- west and the wooded savannah in the middle belt and the northern part of the country. Nigeria ranks among the countries of the world with abundant forest resources. [4] reported that, forests in Nigeria occupied about $110,890 \mathrm{~km}^{2}$ of the country total land mass of about $910,770 \mathrm{~km}^{2}$, this constitute about $12.18 \%$ of the total vegetation cover of the country. According to [5] about 60 percent of all known

Copyright @ 2020: This is an open-access article distributed under the terms of the Creative Commons Attribution license which permits unrestricted use, distribution, and reproduction in any medium for non commercial use (NonCommercial, or CC-BY-NC) provided the original author and source are credited. 
species of plant, about 90 percent of all the world's non-human primates such as monkeys, about 40 percent of all the birds of prey and about 80 percent of all the insects live in the tropical rainforests of the world. Forest ecosystem provides us with varieties of ecosystem services, including cultural and supportive services. These ecosystem services not only deliver the basic material needs for survival, but also underlie other aspects of wellbeing, including health, security good social relations and freedom of choice. In the past, timber production was regarded as the dominant function of forests; recently this perception has shifted to a more multifunctional and balanced view [6]. Today, it is understood that forest biodiversity underpins a wide range of goods and services for human survival.

Ecologically, forested areas store and purify drinking water, help in mitigating natural disasters such as drought and floods, they help in storing carbon and regulating the climate, they provide food and produce rainfall, and they provide a vast array of goods for medicinal cultural and spiritual purposes [7] which in turn support agricultural productivity (i.e. improve crop yield and provide fodder for animals). Similarly, most Nigerians have always depended on the forest for their survival, economic development, as well as environmental amelioration. The level of community nutrition is sometimes linked to fuel wood availability and cost, others depended directly on forest for their livelihood; among them are a high number of forest and wood worker [8]. This part contributes substantially to the National Gross Domestic Product (GDP). In spite of its importance, the natural forest has continued to diminish rapidly in the world especially in Africa continent and particularly in Nigeria. According to [9] about $60 \%$ of deforestation in the tropics occur as a result of agricultural settlement (expansion of land for farming activities). Taking into consideration the fact that more than $80 \%$ of the Nigeria populace are farmers, one can understand the concern of environmentalists on agricultural induce deforestation in the country. In farming practice, site is prepared through under brushing and felling of trees leading to deforestation, slash and burning activities in tropics utilized during shifting cultivation led to permanent destruction of the rainforest [10]. Many reports indicated shifting cultivation as one of the reasons for fast depletion of about one half of tropical forest and some put it up to two thirds [11].

Global water cycle is absolutely disrupted as a result of deforestation. Soil can no longer hold much water leading to dry climate. Water resource elements are negatively altered by deforestation; drinking water, fisheries and aquatic habitats, flood/drought control and damage to crops and irrigation systems from erosion and turbidity [12]. Forests function as natural filter; they filter runoff and also regulate water flow checking flooding. Deforestation results in downstream flooding leading to disaster. A number of flooding incidences were recorded In Nigeria leading to loss of lives and properties worth millions of naira. The long-term effect of deforestation on the soil resources is unquantifiable. Vegetation clearing for slash and burning tends to expose soil to high intensity radiation and torrential rainfall [6]. The absence of appropriate forest management and utilization, land tenure policy and lack of compatible forest legislations could result to deforestation. However, Population growth and the associated expansion of agricultural lands is the primary cause of present-day deforestation [13, 14]. Generally, forest ecosystem has been used constantly to strike ecological balance by trying to cope with the way in which human beings use natural resources, clear forestlands, harvest trees and contaminate the air, land and water. Thus, afforestation and reforestation form a background to the important development taking place in the forestry landscape in the country, particularly land use practices including forest and land allocation, exploitation and environmental conservation. Sustainable afforestation and tree planting program are imperative in Imo State like many other States in Nigeria.

\section{Materials ANd Methods Study area}

This study was conducted in Gaya local Government Area of Kano State Nigeria. It is located on latitude $11^{\circ} 12^{\prime}$ $\mathrm{N}$ and longitude $9^{\circ} 12^{\prime} \mathrm{E}$. It is bordered in the North by Ajingi Local Government, to the West by Wudil Local Government, to the South by Albasu Local Government, and to the East by Dutse Local Government area of Jigawa State. Gaya Town is the headquarter of Gaya Local Government, established in 1976, and it is located in the southern part of Kano State with a distance of $65 \mathrm{Km}$ from Kano City. Gaya has an estimated population of about 201,016 [15]. The soil types are mainly sandy, loamy and brown to reddish brown in color; however, alluvial soils are found around rivers which makes the soil highly productive. The natural vegetation of the study area falls under Sudan Savannah type [16]. It is composed of variety of tree species scattered over an expanse of grassland. The types of trees mostly found in the study area include Adansonia digitata, (baobab), Acacia species, Mahogany, Azaradica indica and Eucalyptus species etc. The precipitation occurs during the summer month starting mostly from May and ends in October. The beginning and length of rainfall vary from year to year. The highest amount of rainfall is characterized by strong wind, thunder and lightning. The showers are intense and last for short period. The average rainfall in a normal year is about $864.1 \mathrm{~mm}$. The dominance of wind system in this region marked the period of dry season, which is partly dry and hot and the dry and cold. The dry hot season period is between March and May. 


\section{Sampling procedure and Sampling size}

Reconnaissance survey was carried in order to get acquainted with the study area, determine the demography and economic activities of the respondents. Gaya Local Government constitute eleven wards (Balan, Gaya, Garmarya, Gamoji, Gaya Arewa, Gaya Kudu, Kademi, Wudiyawa, Shagogo, Maimakawa, Kazurawa) three of these districts were selected at random through balloting, proportional sampling was used in selecting villages.

Table-1: Sampling Procedure used in the study Area

\begin{tabular}{|l|c|c|c|}
\hline Wards & Number of Villages & Sampled villages & No. of respondents \\
\hline Balan & 11 & 3 & 30 \\
\hline Shagogo & 13 & 4 & 40 \\
\hline Kademi & 17 & 5 & 50 \\
\hline Total & 41 & 12 & 120 \\
\hline
\end{tabular}

Source: Field Survey 2019

\section{Data Collection}

Primary and Secondary information were used for this study. One hundred and Twenty questionnaires were administered, retrieved and analyzed while the secondary information was obtained from relevant literatures, text book, journals, past projects and internet.

\section{DAta AnAlysis}

The data obtained were screened, organized and analyzed using descriptive and inferential statistics. The statistical tool to be used includes percentages, pie-chart, frequency distribution and chi-square to test association between socioeconomic characteristics and the dependent variables (deforestation). SPSS version16 was used for the analysis.

\section{RESULTS AND DISCUSSION}

\section{Socioeconomics Characteristics of the Respondents}

Socio-economic characteristics of the respondents is said to be their personal characteristics and conditions assumed to influence decision making. The socioeconomic status considered in this study include age, sex, marital status, level of education, household size, level of awareness, among others.

\section{Age distribution of the respondents}

Figure 1 below shows the age distribution of respondents. It was revealed that majority of the respondents 43 (35.8\%) were between the age ranges of 48-58 years, while those with 37-47 years were representing 39 (32.5\%). Also, 29 respondents (24.2\%) made up 59 and above years, while 9 respondents (7.5\%) are between 15-25 years old.

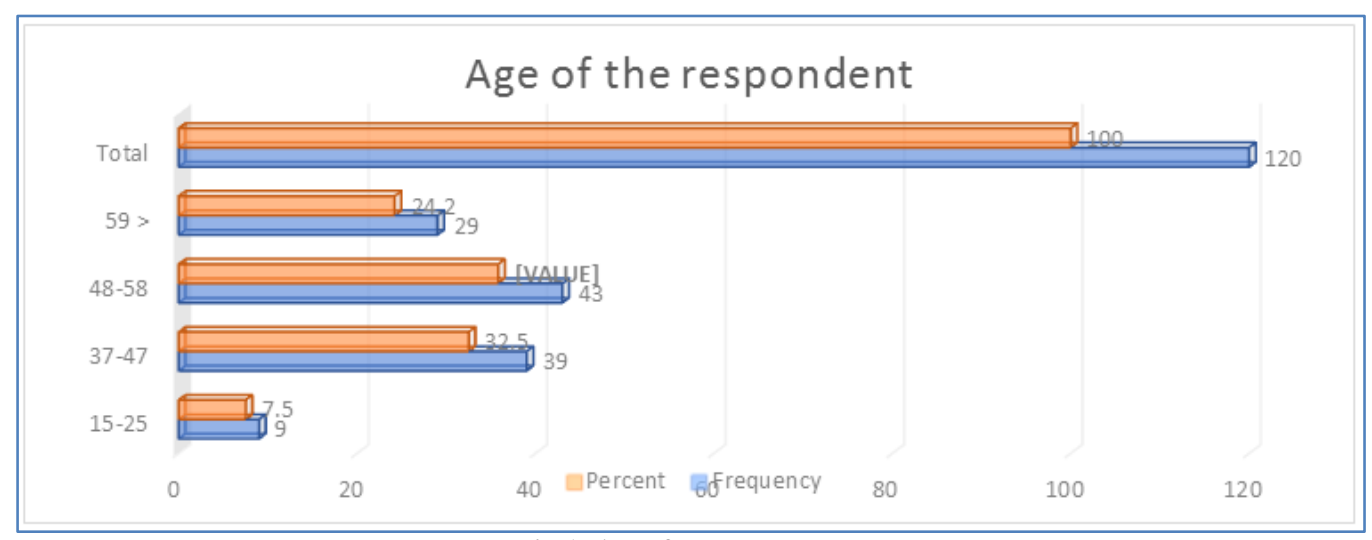

Fig-1: Age of the respondents

\section{Gender of the respondents}

Figure 2 shows the distribution of respondents by gender. It indicated that out of 120 respondents 109 (91\%) were males and $11(9 \%)$ were females. This revealed that there are more male farmers than female farmers in the study area as their work revolve around house hold chores. This does not presuppose that, male is more in number than the female in the entire study area, similar result was obtained by [18]. 


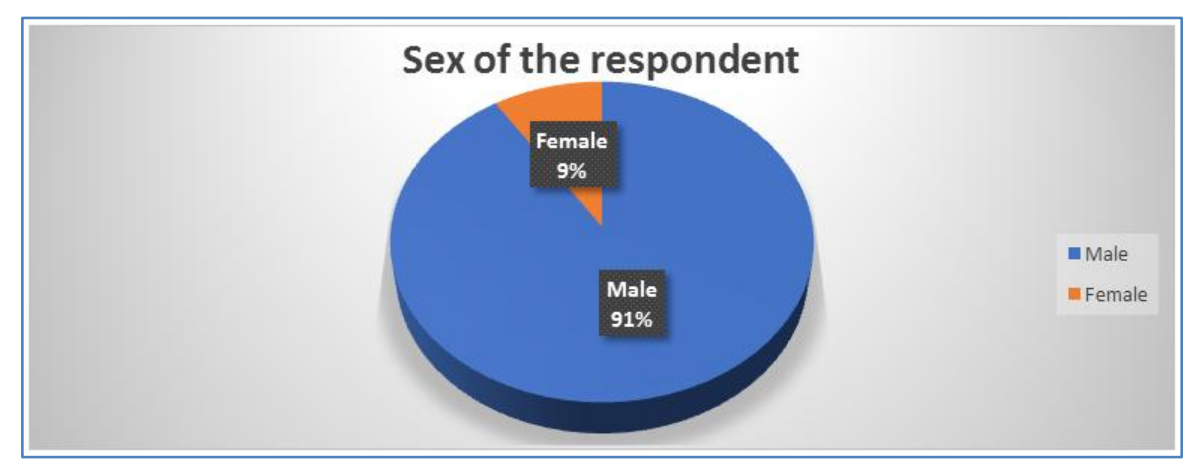

Fig-2: Gender of the respondents

\section{Marital status of the respondents}

The result from the research shows that $94(78.3 \%)$ of the respondent are married and $6(5 \%)$ are single, while 4 $(3.3 \%)$ are divorced and $16(13.3 \%)$ are widow. From this we can deduce that, the majority of the respondent is married.

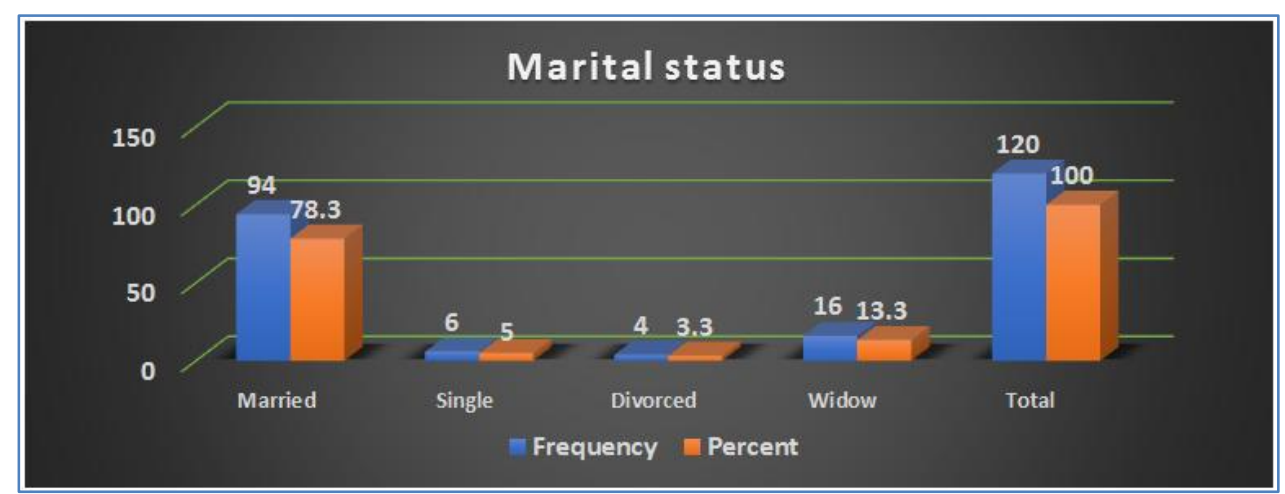

Fig-3: Marital status of the respondents

\section{Household size}

A household unit comprises the household head, wife or wives, children and other dependents living with them. From the results in the table below shows that, there are more respondents with household size ranges from 4-7, having a frequency of 49 and 39.2 percent.

Table-2: Household size

\begin{tabular}{|l|c|c|}
\hline Household & Frequency & Percentage (\%) \\
\hline $0-3$ & 9 & 7.5 \\
\hline $4-7$ & 49 & 39.2 \\
\hline $8-11$ & 31 & 25.8 \\
\hline$>12$ & 33 & 27.5 \\
\hline Total & $\mathbf{1 2 0}$ & $\mathbf{1 0 0 . \%}$ \\
\hline
\end{tabular}

\section{Educational status of the respondent}

Table 3 shows the educational status of the respondent 61(50.8\%) being the highest with non-formal education (Qur'anic literacy), 54 (45.) the majority of the respondents to have attend secondary school 3(2.5) respondents did complete primary school only $3(1.7 \%)$ of the respondent attend tertiary institution. This indicated that majority of respondent (farmers) are informally educated.

Table-3: Educational status of the respondents
\begin{tabular}{|l|l|l|}
\hline Educational status & frequency & percentage \\
\hline Primary & 3 & 2.5 \\
\hline Secondary & 54 & 45.0 \\
\hline Tertiary & 2 & 1.7 \\
\hline Non-formal & 61 & 50.8 \\
\hline Total & $\mathbf{1 2 0}$ & $\mathbf{1 0 0}$ \\
\hline
\end{tabular}




\section{Occupation of the respondents}

The figure above shows the occupation of the respondent, frequency and percentage of the distribution are as follows, farming, business, civil servant with 113 (94.2\%), 3 (2.5\%) and 4 (3.3\%) frequency and percentage respectively.

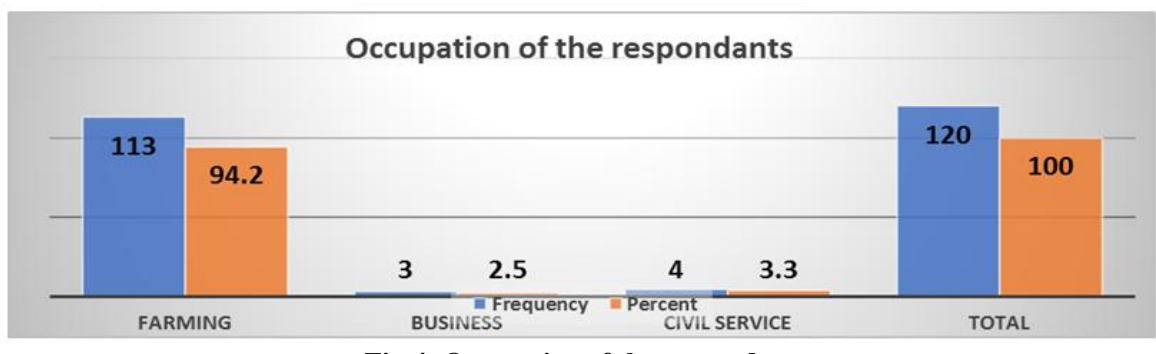

Fig-4: Occupation of the respondent

\section{Types of Farming practice}

The types of farming practice in the locality are basically three, which are mixed farming, mixed cropping and agroforestry. $70 \%$ of the sampled population are practicing mixed farming, $21.7 \%$ Mixed cropping and the lowest value was obtained from agroforestry with $8.3 \%$, this shows that majority of the farmers in the study area do not plant trees which are very important in conserving nutrients, moisture and farmland protection from wind and water erosion.

Table-4: Farming practices of the respondents

\begin{tabular}{|l|c|c|}
\hline Farming practice & Frequency & Percentage \\
\hline Mixed Farming & 84 & 70.0 \\
\hline Mixed cropping & 26 & 21.7 \\
\hline Agroforestry & 10 & 8.3 \\
\hline Total & $\mathbf{1 2 0}$ & $\mathbf{1 0 0 . 0}$ \\
\hline
\end{tabular}

\section{Perception of Farmer on Deforestation}

This presents the descriptive and chi-square analysis of the respondents' opinion concerning cutting of trees, its implication on environment, productivity, the medium through which farmers get information on deforestation, type of farming practiced and reason behind deforestation in Gaya local government area Kano state.

\section{Reasons for deforestation}

Table 5 below shows the results on reasons for deforestation, according to them, major reasons behind cutting down of tree in the sampled area are firewood as source of fuel for domestic purpose takes the first place with 67 (55.8\%) followed by expansion of farm land $30(25 \%)$ and then income as the last reason for cutting down of trees 23 (19.2\%). It's therefore worthy to note that with the provision of alternative source of fuel such as methane gas and kerosene the rate of deforestation can be reduced to minimum

Table-5: Reasons for deforestation

\begin{tabular}{|l|c|c|}
\hline Major purpose of deforestation & Frequency & Percent \\
\hline Firewood & 67 & 55.8 \\
\hline Income & 23 & 19.2 \\
\hline land expansion of land & 30 & 25 \\
\hline Total & 120 & 100.0 \\
\hline
\end{tabular}

Sources of Information on Deforestation

According to findings from this research work, farmers in the study area get information from the radio than any other source $54.2 \%$ of the entire 120 respondents, $4 \% 0 \%$ from extension agents, $4.3 \%$ from television and the least was internet having $1.7 \%$. From this we can conclude that the area has no electricity and majority of the farmers cannot afford a television.

Table-6: Sources of Information on Deforestation

\begin{tabular}{|l|c|c|}
\hline Source of information & Frequency & Percent \\
\hline Radio & 65 & 54.2 \\
\hline Television & 5 & 4.2 \\
\hline Internet & 2 & 1.7 \\
\hline Extension agent & 48 & 40.0 \\
\hline Total & 120 & 100.0 \\
\hline
\end{tabular}




\section{Effects of Deforestation on Productivity}

From the research we found that, the major effect of deforestation on productivity is loss of nutrient, desertification and erosion (wind and water). Surprisingly, all the sampled populations are aware of the effect of deforestation on agricultural productivity but still cutting is taking place in their farms and no any effort for planting is made by the farmers.

Table-7: Effect of deforestation on productivity.

\begin{tabular}{|l|c|c|}
\hline Effect deforestation on productivity & Frequency & Percent \\
\hline Causes erosion & 20 & 16.7 \\
\hline Loss of nutrient, desertification & 100 & 83.3 \\
\hline Total & 120 & 100.0 \\
\hline
\end{tabular}

\section{Relationship between Socio-economic Characteristic and Deforestation}

Chi-square test of association was carried out in order to investigate the relationship between socioeconomic characteristics of the respondents and deforestation (i.e. Ideas and causes).

Results of the test revealed non-significant association between the socioeconomic characteristics and ideas on deforestation (A) as presented in Table 8, the results for the causes of deforestation revealed a significant relationship with all the socioeconomic characteristics with the exception of gender.

Table-8: Chi-square table for Socio-economic Characteristic and Deforestation

\begin{tabular}{|l|c|c|c|}
\hline Variables & \multicolumn{1}{|c|}{$\mathbf{X}^{\mathbf{2}}$} & df & P-value \\
\hline (A)Ideas on deforestation & \\
\hline Age & 2.891 & 3 & 0.409 \\
\hline Sex & 0.527 & 1 & 0.468 \\
\hline Marital status & 3.411 & 3 & 0.328 \\
\hline Household size & 2.810 & 3 & 0.422 \\
\hline Education status & 0.599 & 3 & 0.897 \\
\hline Occupation & 0.323 & 2 & 0.851 \\
\hline (B) Causes of deforestation \\
\hline Age & 53.692 & 9 & $0.001 *$ \\
\hline Sex & 7.787 & 3 & 0.460 \\
\hline Marital status & 52.924 & 9 & $0.001 *$ \\
\hline Household size & 49.332 & 9 & $0.001 *$ \\
\hline Education status & 36.807 & 9 & $0.001 *$ \\
\hline Occupation & 35.630 & 6 & $0.001 *$ \\
\hline \multicolumn{4}{|c}{ *significant $(\mathrm{P}<0.05)$} \\
\hline
\end{tabular}

\section{CONCLUSION AND RECOMMENDATION}

Conclusively, there were more male than the female farmers in the study area, most of the respondents have no formal education. There was no significant relationship between demography and ideas people have about deforestation (i.e whether one is male, female, young, old, or education, everyone can have the idea on deforestation) On the causes of deforestation, all have strong relation except gender, there was significant relation between age, household size and planting of trees on the farmlands.

The researcher strongly recommends the followings: Government should provide a vastly expanded funding mechanism; Extension services are strongly needed to enlighten farmers to adopt planting of trees and arable crops on the same land (Agroforestry) to achieve sustainability between agriculture and environment. There should be a specific program for women in agriculture so as have more women in farming enterprise as the sector is dominated by men.

\section{REFERENCES}

1. FAO. (2011). Global Forest Resources Assessment 2000: Food and Agriculture Organization of the United Nations Rome. Italy

2. FAO. (2010). Global forest resources assessment. Country report. United republic of Tanzania. 20 - 55.

3. Ngaga, Y.M. (2011). Forest plantation and woodlots in Tanzania. African Forest Forum Working Paper Series, $1(16), 1-30$. 
4. Mfon, P., Akintoye, O.A., Mfon, G, Olorundami, T., Ukata, U., \& Akintoye, T. A. (2014). Challenges of Deforestation in Nigerian and the Millennium Development Goals. International Journal of Environment and Bioenergy, 9(2), 76-94.

5. Park C. C. (1992). Tropical Rain Forests. London, Routledge.

6. Ogundele, A. T., \& Oladipo, M. O. (2016). Deforestation in Nigeria: The Needs for Urgent Mitigating Measures. Journal of Geography and Environmental Management, 2(1), 15-26.

7. CBD. (2009). Sustainable Forest Management, Biodiversity and Livelihoods: A Good Practice Guide. Montreal, $47-$ 111

8. Aliyu, A., Modibbo, M.A., Medugu, N.I., \& Ayo. O. (2014). Impacts of Deforestation on socio-Economic Development of Akwanga Nasarawa State. International Journal of Science, Environment and Technology, 3(2), $403-416$

9. Myers, N., \& Mittermeter, R.A. (2000). Biodiversity Hotspots for Conservation Priorities. Nature 403,853-854

10. Nwoboshi, L.C. (1982). Tropical Silviculture Principles and Techniques. Ibadan, University Press.

11. Chakravarty, S., Ghosh, S.K., Suresh, C.P., Dey, A.N., \& Shukla. G. (2012). Deforestation: Causes, Effects and Control Strategies Global Perspectives on Sustainable Forest Management; In A. Okia (Ed) Global Perspectives on Sustainable Forest Management. Available online: http//www.Intechopen.com/books/global-perspectives-onsustainable-forest-management/deforestation-causes-and-control strategies

12. Bruijnzeel, L. A., Bonell, M., Gilmour, D. A. and Lamb, D. (2005). Forest, Water and People in the Humid Tropics: An Emerging View. In M. Bonell, and L.A. Bruijnzeel, (eds) Forest, Water and People in the Humid Tropics. United Kingdom. Cambridge University Press. IARD International

13. Gibbs, H.K. Ruesch, A.S. Achard, F. Clayton, M.K. Holmgren, P. Ramankutty, N., \& Foley J. A. (2010). Tropical forests were the primary sources of new agricultural land in the 1980s and 1990s. Proceedings of the National Academy of Sciences of the United States of America, 107(38), 16732-16737.

14. Foley, J. A., Ramankutty, N., Brauman, K. A., Cassidy, E. S., Gerber, J. S Johnston., M.N. Mueller., D. O’Connell, C. Ray, D. K. West, P. C. Balzer, C. Bennett, E. M. Carpenter, S. R. Hill, J. Monfreda, C. Polasky, S. Rockström., J. Sheehan., J. Siebert., S. Tilman, D., \& Zaks, D. P. M. (2011). Solutions for a cultivated planet. Nature, 478, 337342 .

15. Olofin, E. A. (1987). Some aspects of the physical geography of the Kano region and related human responses. Departmental Lecture Note Series: Geography Department, Bayero University. Debis Standard Printers, Kano, Nigeria

16. Nzeh, C.E.P. (2012). Economic Analysis of Deforestation in Enugu State, PhD Thesis Submitted to Nigeria Department of Agricultural Economics University of Nigeria Nsukka 